\title{
Wspomnienie o dr Lenie Kondratiewej-Bryzik
}

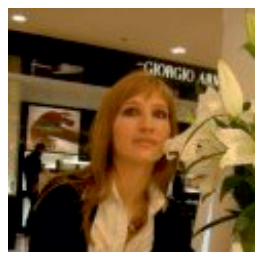

Tragicznym zrządzeniem losu przychodzi mi pisać wspomnienie o Lenie. Według normalnego porządku rzeczy to ona powinna być autorką epitafium dla mnie. Nie wątpię, że podobnie jak wszystko co robiła, i ten tekst byłby znakomity. Wydawać by się mogło, że opisanie dorobku życiowego bardzo młodej, zaczynającej dopiero wspaniale rozwijającą się karierę naukową uczonej nie powinno nastręczać większych trudności. Jednak Lena i pod tym względem jest osobą wyjątkową. Jej szerokie zainteresowania badawcze, ogromna pracowitość i rzetelność oraz wszechstronność pasji życiowych sprawiają, że nie jest łatwo w krótkim tekście zaprezentować całe bogactwo jej dokonań.

Lena urodziła się w Woroneżu 7 września 1980 r. Była jedynym dzieckiem Marii i Aleksieja Kondratiewych. Odebrała bardzo staranne wykształcenie. $\mathrm{Z}$ wyróżnieniem ukończyła zarówno Woroneskie Technikum Prawnicze, jak i wyższe studia prawnicze na Wydziale Prawa Woroneskiego Uniwersytetu Państwowego. Przez okres roku w latach 2001 - 2002 była doktorantką w katedrze prawa konstytucyjnego tego uniwersytetu. Warto podkreślić, że jeden z jej referatów zaprezentowanych w kwietniu 2002 r. na Uniwersytecie w Woroneżu uznany został za najlepszą prezentację roku w dziedzinie - prawo konstytucyjne, prawo międzynarodowe. Tak więc już w początkach swojej kariery akademickiej odnosiła sukcesy.

Do Polski Lena przyjechała w 2002 r. Od tego czasu Polska stała się jej drugą ojczyzną i tu wspaniale rozwinęła swoją karierę zawodową. W tym samym roku Lena rozpoczęła studia doktoranckie w Instytucie Nauk Prawnych PAN. Zamierzała podjąć badania naukowe w szeroko rozumianej 
dziedzinie praw człowieka. Jej pierwszym opiekunem naukowym był prof. Adam Łopatka. Nie mogła lepiej trafić. Prof. Łopatka był znakomitym wychowawcą młodzieży i pomógł Lenie uwierzyć w siebie i w to, że w Polsce może ona z powodzeniem konkurować z najlepszymi. Po śmierci prof. Łopatki zostałem opiekunem naukowym Leny i promotorem jej pracy doktorskiej, którą w bardzo dobrym stylu obroniła przed Radą Naukową INP PAN dnia 28 listopada 2008 r. Temat pracy był bardzo ambitny i trudny zarazem. Dotyczyła ona bowiem początku prawnej ochrony życia ludzkiego w świetle standardów międzynarodowych. Trzeba pamiętać, że w Rosji, w odróżnieniu od Polski, obowiązują bardzo liberalne przepisy regulujące kwestię aborcji. Można było obawiać się, jak praca będzie przyjęta w Polsce. Lena zachowała jednak dystans badawczy do przedmiotu analizy i zweryfikowała wiele swoich początkowych opinii. Udało się jej przeprowadzić bardzo rzetelną i udokumentowaną rekonstrukcję standardu międzynarodowego i na tej podstawie krytycznie ocenić polską praktykę. Krytycznie oceniła też prawo i praktykę jego stosowania w Rosji.

Warto w tym miejscu przytoczyć końcowy fragment książki opracowanej na podstawie doktoratu, wydanej nakładem wydawnictwa Wolters Kluwer w czerwcu 2009 r. Autorka stwierdziła: „w oparciu o przeprowadzona analizę obowiązujacych obecnie na poziomie uniwersalnym i regionalnym (europejskim) standardów międzynarodowych stwierdzam, że brak zapewnienia nasciturusowi ochrony prawa do życia $w$ ustawodawstwie krajowym nie jest sprzeczny z wyżej wymienionym standardami. Do sprzeczności takiej dojdzie natomiast w sytuacji, gdy ustawodawca krajowy, decydując się na objęcie ochrona prawa do życia nasciturusa, podczas rozstrzygania ewentualnych kolizji przy szukaniu równowagi pomiędzy ochrona płodu i praw człowieka przysługujących kobietom, będzie nadawał priorytet ochronie płodu”.

Praca uzyskała nagrodę w konkursie „Państwa i Prawa” w 2010 r. i była przedmiotem licznych aprobujących recenzji naukowych i niezliczonej ilości cytowań.

W 2009 r. Lena została adiunktem w Poznańskim Centrum Praw Człowieka INP PAN. Mimo, iż mieszkała nadal w Warszawie, regularnie uczestniczyła w seminariach naukowych, konferencjach, zebraniach i innych przedsięwzięciach organizacyjnych Centrum. Bardzo szybko dała się poznać jako świetny fachowiec, a zarazem miła i uczynna koleżanka. Była jednym z filarów naszego zespołu i źródłem licznych, bardzo ciekawych inspiracji na- 
ukowych. Nie sposób wyliczyć wszystkie jej osiągnięcia naukowe - artykuły, glosy, opinie, ekspertyzy, referaty na konferencjach naukowych. Trzeba jednoznacznie stwierdzić, że jest to dorobek imponujący jakościowo i ilościowo. Była współredaktorką dwóch prac zbiorowych. Z prof. Wojciechem Sokolewiczem książki pt. „Prawa kobiet we współczesnym świecie oraz z prof. Mirosławem Wyrzykowskim i ze mną książki pt. „Prawne granice wolności sumienia i wyznania”. Pracowała na kolejną publikacją poświęconą zagadnieniom bioetycznym.

Zainteresowania badawcze Leny, w ramach szeroko pojętej problematyki międzynarodowej ochrony praw człowieka, obejmowały takie kwestie jak: prawa prokreacyjne, ochrona praw kobiet, ochrona przed dyskryminacją, zagadnienia bioetyczne, itp. Habilitację zamierzała napisać na temat kwestii wpływu wyroków Europejskiego Trybunału Praw Człowieka na praktykę stanowienia i stosowania prawa w porządkach krajowych państw stron Europejskiej Konwencji Praw Człowieka. Miała już na ten temat sporo przemyśleń i wystąpień na seminariach naukowych. Nie wątpię, że byłaby to znakomita praca.

Na szczególne podkreślenie zasługuje fakt, że w uznaniu jej dotychczasowego dorobku i nadziei, jakie ów dorobek rokował na dalszy rozwój naukowy, Lena otrzymała prestiżowe stypendium dla młodych naukowców START 2011 przyznawane przez Fundację na Rzecz Nauki Polskiej. Zważywszy, że Lena była cudzoziemką, jest to osiągnięcie bardzo znaczące.

Oprócz działalności badawczej Lena prowadziła też zajęcia dydaktyczne. Była w ostatnim okresie zatrudniona na Wydziale Prawa w Wyższej Szkole Zarządzania i Prawa im. Heleny Chodkowskiej w Warszawie. Prowadziła też m. in. zajęcia w Centrum Europejskim Uniwersytetu Warszawskiego, na Wydziale Prawa SWPS. Od kilku lat prowadziła w języku angielskim tzw. case study dla słuchaczy dorocznych kursów pt. „Międzynarodowa ochrona praw człowieka. Ochrona praw mniejszości” organizowanych przez Poznańskie Centrum Praw Człowieka. Prowadziła podobne zajęcia w ramach letniej szkoły organizowanej przez Uniwersytet Viadrina we Frankfurcie nad Odrą. Lena miała dar szybkiego nawiązywania kontaktu ze słuchaczami i umiejętność wciągania ich w dyskusję. Zarazem była bardzo utalentowana lingwistycznie. Po polsku mówiła bez akcentu, biegle władała angielskim, porozumiewała się po francusku, uczyła się hebrajskiego. 
Chętnie i aktywnie uczestniczyła w życiu naukowym środowiska prawniczego. Nie sposób wymienić konferencje, w których brała udział wygłaszając ciekawe i inspirujące wykłady. Była członkiem Polskiego Towarzystwa Prawa Konstytucyjnego oraz Grupy Polskiej Stowarzyszenia Prawa Międzynarodowego (ILA).

Lena aktywnie działała na forum organizacji pozarządowych. Była stałą współpracowniczką Koalicji KARAT, Helsińskiej Fundacji Praw Człowieka, Federacji na Rzecz Kobiet i Planowania Rodziny, Polskiego Stowarzyszenia Edukacji Prawnej, itp.

Obraz Leny byłby bardzo zubożony gdyby pominąć jej zainteresowania muzyką - śpiewała w Chórze Akademickim Uniwersytetu Warszawskiego oraz literaturą, filmem, teatrem. Z zaangażowaniem uczestniczyła też w różnych formach dialogu polsko - rosyjskiego. Czując się Rosjanką była zarazem Polką i bardzo zależało jej na dobrych relacjach międzyludzkich pomiędzy obu krajami.

Wszyscy, którzy mieli szczęście zetknąć się z Leną w życiu zawodowym lub prywatnym byli pod wrażeniem jej głębokiej kultury osobistej, delikatności i subtelności. Była osobą bardzo sumienną, systematyczną i świetnie zorganizowaną. Wyniosła to $\mathrm{z}$ domu rodzinnego. Otoczona miłością swojej rosyjskiej rodziny, z która utrzymywała niemal codzienny kontakt, znalazła jednak swoje miejsce w życiu w Polsce. Polubiła Warszawę i znała ją i jej historię lepiej niż wielu rodowitych warszawiaków. Myślę, że właśnie w naszym kraju uzyskała świetne warunki do rozwoju swoich zainteresowań badawczych i poznawczych. Dorobek naukowy Leny na trwałe wpisał się do polskiego prawoznawstwa. Chciałbym również głęboko wierzyć, że będzie on dla nas inspiracją w naszych pracach.

Non omnis moriar Leno. 